\title{
Broken noses for the gods: ritual battles in the Atacama Desert during the Tiwanaku period
}

\author{
Andrea Lessa $^{+}$, Sheila Maria Ferraz Mendonça de Souza \\ Departamento de Endemias Samuel Pessoa, Escola Nacional de Saúde Pública Sergio Arouca-Fiocruz, \\ Rua Leopoldo Bulhões 1480, 21041-210 Rio de Janeiro, RJ, Brasil
}

The sample consists of 226 skulls from the Atacameño cemetery of Coyo Oriente (639-910 AD), associated with the Tiwanaku period. The authors analyzed signs of acute trauma typically associated with violence, and the results were $12 \%$ of men and $9.9 \%$ of women displaying any type of lesion related to violence. In males, concentration of these non-lethal lesions in the nasal region (10.4\%) as opposed to a random distribution over the entire skull (1.6\%), suggests that the blows were struck during rituals. The cultural context of this period, with a strong ideological influence from Tiwanaku, supports the ritual hypothesis, since both the ethnographic as well as archeological records point to the existence of non-lethal violent bleeding with ritual beating to the face. Such rituals persist to this day among certain Andean populations. Among women, the most plausible hypothesis for the lesions (3.9\% in the skull, $4.9 \%$ in the nasal bones, and $0.9 \%$ in the face) is domestic conflicts, since they show a random distribution. Previous studies with other Atacameño samples had indicated the same results for women.

Key words: palaeoepidemiology - acute trauma - nasal fractures - ritual fights - Coyo Oriente - Tiwanaku - San Pedro de Atacama

The Atacama Desert, were the Atacameño culture flourished for more than two thousand years, is located in the southern part of the Andean region, in Northern Chile (Fig. 1). The local economy in that extremely arid environment was based on herding camelids, growing a limited variety of crops, and trading such produce (Nunez 1992). One of the most important Atacameño groups occupied small ayllus (villages) in the oasis of San Pedro de Atacama.

San Pedro de Atacama's strategic geographical location in the heart of the desert, close to the salares or salt marshes, assured the long-lasting hegemony of their trade routes and trade system. Because of trade caravan activities, Atacama was especially important for other groups like the Tiwanaku Federation which was extending its territories and expanding its political and economic power (Núñez 1992, Núñez \& Dillehay 1995).

Between 1950 and 1970, several pre-Columbian cemeteries were excavated in San Pedro de Atacama, including Coyo Oriente. Numerous grave goods were dated by radiocarbon analysis to between 639-20 AD and 910-90 AD (Oakland 1992), and by thermoluminescence to 790 AD (Berenguer et al. 1988). These dates confirm the site's chronology, associated with the Tiwanaku period, previously defined on the basis of the stylized burial goods, especially pottery (Tarragó 1968). This period's most striking characteristic was the intensification of political and economic relations between the Tiwanaku Fed-

Financial support: Capes

${ }^{+}$Corresponding author: lessa@ensp.fiocruz.br

Received 20 July 2006

Accepted 16 October 2006 eration and the Atacameño people. The ideological influence of Tiwanaku can easily be recognized in the complex burial offerings. Some other consequences of Tiwanaku influence over the strategic Atacama oasis are the marked social stratification, increasing power of the shamans, increasing use of hallucinogens, and intensification of mining and metallurgy (Berenguer \& Dauelsberg 1989, Núñez 1992, Núñez \& Dillehay 1995), and the increasing violence in the Atacameño society, as expressed in the Solcor-3 site (Lessa 1999, Lessa \& Mendonça de Souza 2004).

This paper continues previous research on traumatic injuries in samples from the Atacama oasis (Lessa 1999, 2005, Lessa \& Mendonça de Souza 2004) describing and discussing violent lesions in the human remains excavated in Coyo Oriente cemetery. The authors consider the scenario of the Atacameño culture under the ideological influence of the Tiwanaku Federation.

Interest in this theme is based on the premise that ongoing rearrangement of social roles, characterizing the very dynamism of the human societies, feeds the violent events whose causes and consequences are intrinsically associated with each specific cultural context (Lessa \& Mendonça de Souza 2001, Lessa 2004). The current article thus intends to contribute to a better understanding of Atacameño social behavior, beginning with the Tiwanaku period.

\section{MATERIALS AND METHODS}

The Coyo Oriente cemetery was excavated by Gustavo Le Paige, who found 239 graves of individuals from different age groups and both sexes. At the time, only the skulls of skeletonized remains, in addition to 43 whole mummified bodies, were collected (Le Paige 1971). They are all stored and classified at the RP Gustavo Le Paige SJ Archeological Research Institute and Museum.

The material is well-preserved, and all 226 adult skulls available at the museum (from 101 females and 125 males) 


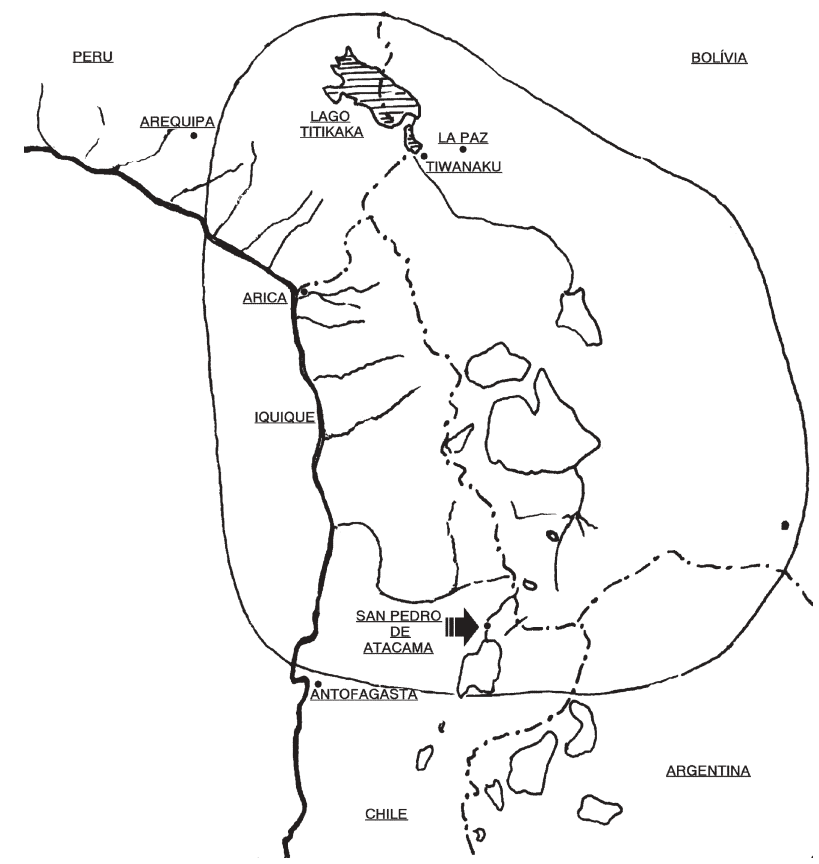

Fig. 1: map of the Atacama Desert and circum-Titicaca region, indicating the approximate location of the San Pedro de Atacama oasis (modified from Berenguer \& Daueslberg 1989).

were analyzed here. Some of the skulls ( 3 males and 15 females) were registered under numbers not found in the laboratory files, and some skulls registered in the original laboratory files could not be found in the storage area, suggesting minor differences between the series described here and that originally recorded by Le Paige.

Acute trauma associated with violence, such as depressed vault fractures and facial-bone crush fractures were considered here, following the literature (Ortner \& Putschard 1997, Walker 1989, 1997). Nasal fractures were considered a special type and were quantified separately. Other evidence of violence, mostly found in bones from elsewhere in the skeleton, could not be considered because only the skulls were available for study.

Fracture diagnosis was based on anatomical and pathological criteria: formation of new bone, absence of bone, bone resorption, interruptions or breaks in anatomical structures, cortical healing indicated by high-density areas, active resorption indicated by porotic areas associated with bone loss, and fissures and depressions that might indicate morphological change associated with trauma (Steinbock 1976, Adams 1976, Merbs 1983, Ortner \& Putschar 1997, Larsen 1997)

Specifically with regard to nasal fractures, clinical studies have demonstrated that these bones are extremely fragile and therefore easily dislocated and fractured. In addition, the fragments can rarely be reduced to the original position or stabilized, thus resulting in badly aligned healing, with aesthetic and functional consequences. On the other hand, there is a high incidence of morphological anomalies in the nasal bones, so that radiography is not an efficient technique for fracture diagnosis (Rubinstein
$\&$ Strong 2000). More severe and lateral traumas force the nasal bones, creating additional fracture lines at the lateral borders of the nasal aperture. Old nasal fracture scars persist for a long time and are especially noticeable when nasal bones are dislocated and heal in an anomalous position, although occasionally bone callus can hide the fracture lines. However, such evidence persists on the inner surface of nasal bones (Walker 1997). To distinguish between morphological anomalies and fractures, the authors considered that only fracture lines, dislocation, and absence of bony fragments were conclusive for the differential diagnosis of trauma.

Children and adolescents were not considered in the present analysis, since violence against younger age groups in any population is scarce and generally associated with child abuse, war, or intentional massacres (Walker 1997). Such violence would be unexpected in Coyo Oriente. Peri-mortem fractures were also excluded because of the problems in differential diagnosis, especially in the absence of technological facilities such as electron microscopy in the Le Paige Museum.

Age and sex estimation had been done previously by the bioanthropologist at Le Paige Museum, Maria Antonieta Costa, who kindly provided this data recorded in the museum files. According to the same files, 122 male skulls and 86 female skulls had their age estimated, while 3 men and 15 women had no age estimation. Individuals were grouped by age as follows: I - 18-29 years; II -30-40 years; III - more than 40 years.

Age was estimated exclusively from cranial and palatal suture closure (Cocilovo et al. 1994). Besides being fairly inaccurate, this variable was not especially informative for the purpose of this paper, so it was not used in quantification of the lesions. Moreover, two male skulls with lesions were not age-estimated, possibly causing a bias in the observed frequencies.

Despite the above limitations, quantification of the sample distribution by age segment was performed to observe whether it followed the same pattern as in other Atacameño samples. The wide age intervals sought to minimize possible estimation errors.

Specific statistical tests show low sensitivity in the presence of low values represented by small variations (Elwood 1998). Therefore, the data's significance was not verified through statistical tests. The discussion here is based on exploratory quantitative analyses, and the interpretations sought to integrate the observed lesion patterns for each social segment with the archeological context of the Tiwanaku period, considering biocultural significance (Mendonça de Souza et al. 2003).

\section{RESULTS}

In Coyo Oriente there was a similar proportional mortality rate for men and women in each age segment. The percentages were, respectively, 4 and $5.8 \%$ for age group I; 56.5 and $56.9 \%$ for age group II; and 39.3 and $37.2 \%$ for age group III. Three men and 15 women were not quantified in this table due to the lack of age estimation.

Fifteen males (12\%) and 10 females $(9.9 \%)$ showed evidence of acute violent lesions. Depressed skull fractures were found in 2 males (1.6\%) and 4 females (3.9\%) 
(Table II). All the fractures were round and small (Fig. 2), except for one in a woman, with multiple fractures of different shapes and sizes, suggesting concomitant trauma. All the fractures had healed, with no sign of infection. There were few fractures in the cranial vault, and it was not possible to propose a distribution for the lesions in relation to either the affected bone or the side of the skull.

Nasal fractures were found in 13 males (10.4\%) and 5 females $(4.9 \%)$ (Table II). In most of the lesions, the nasal bone fragments overlapped or were misaligned due to lateral or frontal blows (Fig. 3). In some cases, missing bone parts suggest that the bone splinter or fragment was completely reabsorbed or expelled.

\section{TABLE I}

Distribution of the Coyo Oriente skeletons ${ }^{a}$ according to age segments

\begin{tabular}{lrrrrr}
\hline & \multicolumn{3}{c}{ Male } & & \multicolumn{2}{c}{ Female } \\
\cline { 2 - 3 } \cline { 6 - 7 } Age & $\mathrm{N}$ & $\%$ & & $\mathrm{~N}$ & $\%$ \\
\hline I & 5 & 4.1 & & 5 & 5.8 \\
II & 69 & 56.5 & & 49 & 57 \\
III & 48 & 39.3 & & 32 & 37.2 \\
\hline Total & 122 & 100 & & 86 & 100 \\
\hline
\end{tabular}

$a$ : not all the individuals analysed in this paper, only the skeletons which had the cathalog number in the Museum records.

\section{TABLE II}

Number of individuals with acute violent traumas according to anatomical region in Coyo Oriente

\begin{tabular}{lcccccc}
\hline & \multicolumn{2}{c}{ Male $(\mathrm{N}=125)$} & & \multicolumn{2}{c}{ Female $(\mathrm{N}=101)$} \\
\cline { 2 - 3 } \cline { 6 - 7 } Lesions & $\mathrm{n}$ & $\%$ & & $\mathrm{n}$ & $\%$ \\
\hline Skull & 2 & 1.6 & & 4 & 3.9 \\
Nasals & 13 & 10.4 & & 5 & 4.9 \\
Face & - & - & & 1 & 0.9 \\
\hline Total & 15 & 12 & & 10 & 9.9 \\
\hline
\end{tabular}

$\mathrm{N}$ : number of individuals examined; $\mathrm{n}$ : number of individuals with lesion.

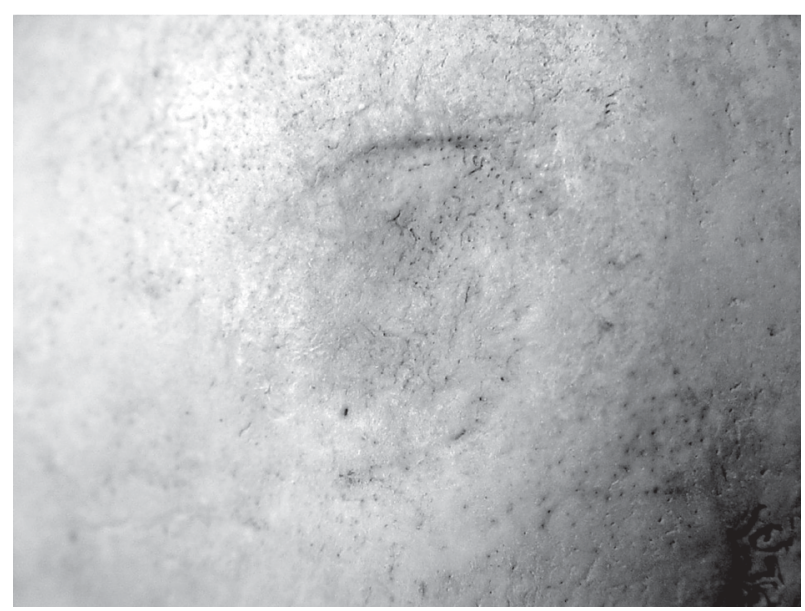

Fig. 2: male skull (\# 4112) with shallow depressed fracture at the frontal bone.

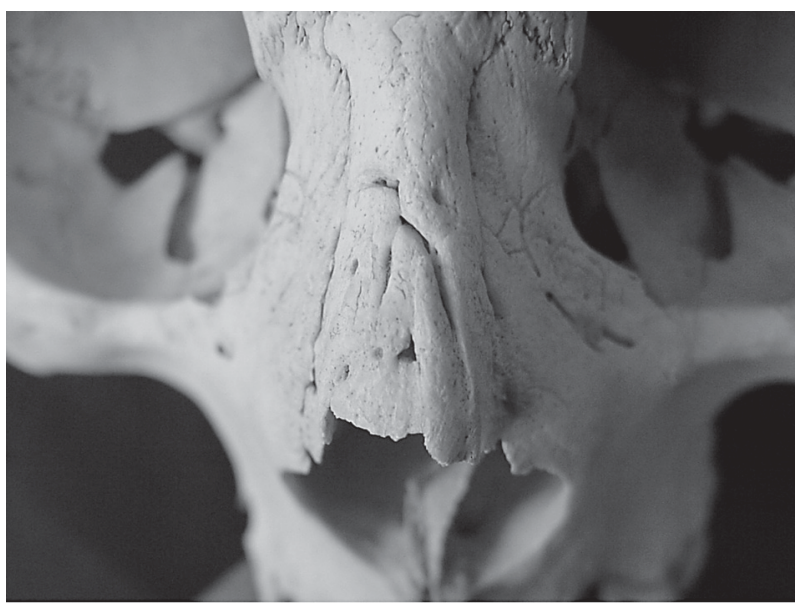

Fig. 3: male skull (\# 5278) with healed fracture of the nasal bones, notice the fracture lines and overlap of bony fragments.

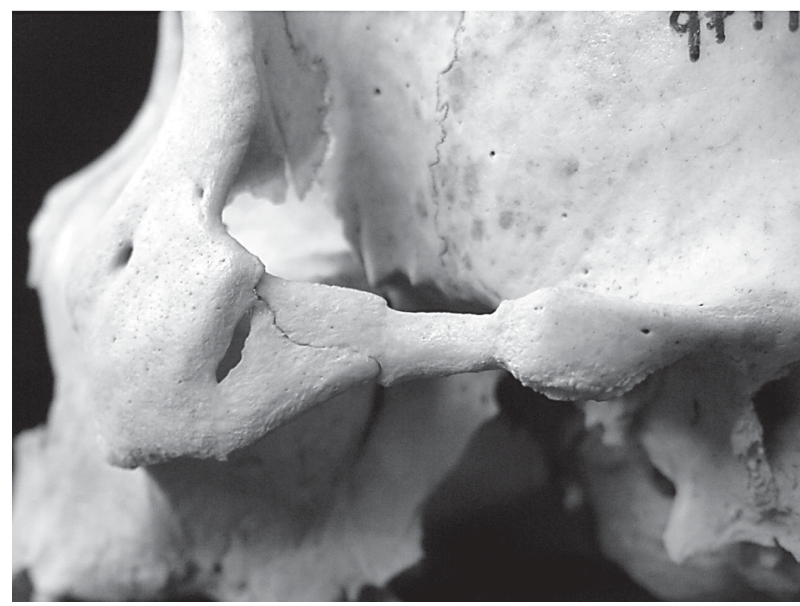

Fig. 4: memale skull (\# 4087) with healed fracture at the left zygomatic bone.

Only one woman $(0.9 \%)$ showed a facial fracture, on the left zygomatic bone (Fig. 4). No skull showed fractures in both the nasal bones and cranial vault.

\section{DISCUSSION}

Considering age-related mortality in Coyo Oriente, most of the individuals died between 30 and 40 years of age, which is consistent with mortality patterns in most pre-historic Amerindian groups. Moreover, the rates were quite similar for men and women, suggesting a similar exposure to risks for both sexes, considering each age bracket.

This situation appears more evident when the mortality data are compared with those of Solcor-3, a site located in the same oasis and associated with the same cultural period. In the latter sample, groups I and II had high proportional age-related mortality, with $47 \%$ each, while age group III showed a lower value (5.9\%). Men less than 30 years of age also presented frequent acute trauma associated with violence (35\% of the total sample, $75 \%$ of the individuals with lesions), indicating that this 
segment was at specific risk and suggesting recurrent episodes of violence (Lessa 1999, Lessa \& Mendonça de Souza 2004). Comparison of the two sites was useful to show that Coyo Oriente males were dying at a natural proportion for age, and that they had less potentially lethal wounds, suggesting no violent cause of death with an epidemiological impact on the Coyo Oriente ayllu.

Although the low frequency of violent lesions indicates that there were few intra- or inter-group conflicts, the location of fractures is quite interesting. Most occurred in the nasal bones, and mostly in males $(10.4 \%$ of the total sample and $86.7 \%$ of the observed lesions). Nonlethal healed lesions were clearly concentrated in this region, contrasting with the lower frequency on the cranial vault $(1.6 \%$ of the total sample and $13.3 \%$ of the observed lesions) and absence of lesions in the face.

Comparing the results from Coyo Oriente and Solcor3 males again, the latter followed the expected probabilistic pattern, with $30 \%$ of the lesions in the cranial vault and only $10 \%$ in the nasal bones. During ordinary interpersonal fights, when opponents are face-to-face or stand apart from each other, blows are struck randomly. Therefore, the probability of a blow striking the skull or facial bones is much greater than that specifically striking the nasal region, which represents a very small area. The concentration of non-lethal fractures in this small area and the absence of lesions elsewhere in the skull would indicate that blows were struck according to specific rules of attack, such as during ritual fights.

For the Coyo Oriente sample specifically, the practice of ritual fights is considered a strong hypothesis when considered within the cultural context of this period. Atacama oases were under strong ideological influence from Tiwanaku, which can be clearly observed in several cemeteries, consistently represented through the complex ceremonial-religious apparatus related to inhalation of hallucinogens (Orellana 1985, Llagostera et al. 1988, Llagostera 1996, Núñez 1992, Núñez \& Dillehay 1995). In Coyo Oriente, a large number of pyrographic bones, tubes, spoons, and especially tabletas or small dishes to place the hallucinogenic powder were found. All of these artifacts presented the typical Tiwanaku iconography, such as the central and secondary themes of the "Puerta del Sol" (Winter et al. 1985, Orellana 1985). These funerary offerings confirm the strong Tiwanaku influence on the above-mentioned ayllu.

Ethnohistorical data and ethnological studies have described ritual fights in both the Aymara people living close to Lake Titicaca and the Quechua in various Andean regions. These peoples are believed to preserve part of the cultural heritage from prehistoric Tiwanaku, including a still persisting well-known ritual fight called tinku in both languages (Isla 1997, Celestino 1997, Duviols 1997).

Such fights are generally described as occurring between different ayllus in the same area. They take place between December and March in order to guarantee successful and productive crops and herding. After drinking some alcoholic beverages, the men appear before their opponents, who beat them into bleeding. This is a dual competition between opposing communities for identity affirmation, but also a fertilization rite and sacrifice to
Pacha mama, the Mother Earth (Celestino 1997, Isla 1997). Different ways of fighting tinku have been described. The duels can occur with the participants lashing each other with the purpose of bleeding the opponent, or they can take turns striking each other with slings (huaracas). The combatants can fight in matches, forming lines, or as free fights using their bare hands (Topic \& Topic 1997).

Paleopathological analysis of skeletons from the Mochica ritual site of Huaca de la Luna revealed skull fractures and broken ribs and long bones, but especially lesions at the borders of the nasal bones, in different stages of healing. They were interpreted as results of blows struck during ritual fights. All 65 individuals were males (Verano 2000). In this case the fractures distributed in different bones point to free fighting, with no specific pattern.

These data confirmed the results of iconographic studies in Mochica pottery, the drawings on which were interpreted as scenes of tinku ritual fights. This emphasizes that opponents did not do free fighting, but always as pairs, all Mochicas and not from different ethnic groups. In such cases the duels were to capture prisoners, who were then sacrificed and had their blood offered to the gods (Hocquenghem 1987).

The ritual fight hypothesis as cause for nasal lesions observed in the Coyo Oriente sample had already been proposed by Arriaza (1992), but his results were different, possibly due to distinct diagnostic methodologies. He observed higher frequencies of nasal lesions for women than for men, and both were interpreted as being caused by ritual fights or low-intensity conflicts. Since his article was only published as an abstract, it is not possible to compare his data, methodology, or interpretation with the current article.

Although our main interpretation for nasal lesions is the practice of ceremonial fights dedicated to gods, other kinds of ritual fights may also have been performed. According to Walker (1997), groups living in geographically limited environments frequently opt to solve their conflicts through ritual duels, once fatal duels tend to reduce the individual's number to that necessary for efficiently accomplishing subsistence activities. Conflict resolution by moving the group elsewhere would not be a viable option in geographically confined environments (Walker 1997). This thus provides an alternative interpretation for ritual fights among Atacameño men, considering the geographical restriction of the oasis for subsistence production.

There was no specific pattern in the violent lesions in females, with $0.9 \%$ in the face, $4.9 \%$ in the nasal bones, and $3.9 \%$ in different bones of the cranial vault. Absence of lethal trauma and the specific pattern of the lesions strongly suggest that they resulted from domestic conflicts, inside or outside the family group (Lambert 1997).

Returning to data from the pre-Tiwanaku and Tiwanaku periods in the Solcor-3 samples, the results suggested the interpretation of domestic violence affecting women (Lessa 1999, Lessa \& Mendonça de Souza 2004). A heterogeneous distribution of the lesions in the head was observed again, with identical frequencies for the two periods. Similar results were observed in the Coyo-3 
sample (Lessa 2005), associated with a brief transition between the Tiwanaku and post-Tiwanaku periods.

The results of the Coyo Oriente sample thus confirm that domestic violence against women was commonplace among Atacameño groups, regardless of political, ideological, religious, and economic changes, and that risk of exposure to violence was different between the sexes.

Concluding, in the Coyo Oriente sample, most individuals died between 30 and 40 years of age, consistent with the mortality pattern in most pre-historic Amerindian groups. Moreover, the mortality rates were quite similar between the sexes in each age bracket, suggesting that violent causes of death did not have an epidemiological impact on the Coyo Oriente ayllu.

Acute violent trauma in this sample was mainly expressed by non-lethal and healed nasal fractures in males. Such fractures had a very specific pattern compatible with ritual fights, possibly the tinku still fought by the Altiplano peoples. Violent trauma in women was less frequent and similar to other samples from the same region, with no specific pattern, suggesting that domestic violence was present in different sites and periods in the Atacama Desert.

\section{REFERENCES}

Adams JC 1976. Manual de Fraturas, Artes Médicas, São Paulo, $306 \mathrm{pp}$.

Arriaza B 1992. Bloody noses, good crops or, ritualistc battles in the Tiwanaku colonies? Proceedings of the Nineteenth Annual Meeting of the Paleopathology Association, Nevada, US.

Berenguer J, Dauelsberg P 1989. El norte grande en la órbita de Tiwanaku (400 a 1200 d.C.). In J Hidalgo, Culturas de Chile - Prehistoria desde sus Origenes hasta los Albores de la Conquista, Ed. Andrés Bello, Santiago, p. 129-180.

Berenguer J, Román A, Deza, A, Llagostera A 1988. Testing a cultural sequence for the Atacama Desert. Curr Anthropol 29: 341-346.

Celestino O 1997. Transformaciones religiosas en los Andes peruanos. Gazeta de Antropologia 13: 1-19.

Cocilovo J, Zavattieri, M, Costa, M.A 1994. Biología del grupo pre-histórico de Coyo Oriental (San Pedro de Atacama, Norte de Chile): I Dimorfismos sexual y variación etária. Estúdios Atacameños 11: 121-134.

Duviols P 1997. Del discurso escrito colonial al discurso prehispánico: hacia el sistema sociocosmológico Inca de oposición y complementariedad. Bull Inst Fr Etud Andines 26: 279-305

Elwood M 1998. Critical Appraisal of Epidemiological Studies and Clinical Trials, Oxford University Press, Oxford, 448 pp.

Hocquenghem AM 1987. Iconografia Mochica, Universidad Católica del Peru, Lima, 280 pp.

Isla A 1997. Transformación de las identidades bajo el terror en América Latina. Diálogo Iberoamericano 9: 19-22.

Lambert PM 1997. Patterns of violence in prehistoric huntergatherer societies of coastal southern California. In DL Martin, DW Frayer (eds), Troubled Times: Violence and Warfare in the Past, Gordon and Breach Publishers,
Amsterdam, p. 77-110.

Larsen CL 1997. Bioarcheology. Interpreting Behaviour from the Human Skeleton, Cambridge University Press, Cambridge, $461 \mathrm{pp}$.

Le Paige G 1971. Tres cementerios indigenas en San Pedro de Atacama Y Toconao. Actas del VI Congreso de Arqueologia Chilena, Universidad de Chile, Santiago, p. 163-187.

Lessa A 1999. Estudo de Lesões Traumáticas Agudas como Indicadores de Tensão Social na População do Cemitério Solcor-3, San Pedro de Atacama, Chile, MSc Thesis, Escola Nacional de Saúde Pública, Rio de Janeiro.

Lessa A 2004. Arqueologia da agressividade humana: a violência sob uma perspectiva paleoepidemiológica. Hist Ciênc Saúde - Manguinhos 11: 279-296.

Lessa A 2005. Paleoepidemiologia dos Traumas Agudos em Grupos Atacamenhos: a Violencia sob uma Perspectiva Diacrônica, PhD Thesis, Escola Nacional de Saúde Pública, Rio de Janeiro.

Lessa A, Mendonça de Souza, SMF 2001. Convívio e conflito: história cotidiana da vida pré-histórica. Inteligência 12: 1831 .

Lessa A, Mendonça de Souza SMF 2004. Violence in the Atacama desert during the Tiwanaku period: social tension? Int $J$ Osteoarchaeol 14: 374-388.

Llagostera A 1996. San Pedro de Atacama: nodo de complementariedad reticular. In X Albó, Integración Surandina: Cinco Siglos Después, Centro de Estudios Regionales Andinos Bartolomé de Las Casas, Taller de Estudios Andinos/ Universidad Católica del Norte, Antofagasta, p. 17-41.

Llagostera A, Torres MC, Costa MA 1988. El complejo psicotrópico en Solcor 3 (San Pedro de Atacama). Estudios Atacameños 9: 61-98.

Mendonça de Souza SMF, Carvalho DM, Lessa A 2003. Paleoepidemiology: Is there a case to answer? Mem Inst Oswaldo Cruz 98 (Suppl.1): 21-28.

Merbs CF 1983. Trauma. In MY Iscan, KAR Kennedy (eds), Reconstruction of Life from the Skeleton, Allan Liss Press, New York, p. 161-189.

Núñez L 1992. Cultura y Conflicto en los Oásis de San Pedro de Atacama, Ed. Universitária, Santiago, 273 pp.

Núñez L, Dillehay TS 1995. Movilidad Giratoria, Armonía Social y Desarrollo en los Andes Meridionales: Patrones de Tráfico e Interacción Económica, Universidad Católica Del Norte, Antofagasta, 190 pp.

Oakland A 1992. Textiles and Ethnicity: Tiwanaku in San Pedro de Atacama, North Chile. Lat Am Antiq 3: 316-340.

Orellana MR 1985. Relaciones culturales entre Tiwanaku y San Pedro de Atacama. Dialogo Andino 4: 247-257.

Ortner DJ, Putschar WGJ 1997. Identification of Pathological Conditions in Human Skeletal Remains, Smithsonian Institution Press, Washington, 469 pp.

Rubinstein B, Strong EB 2000. Management of nasal fractures. Arch Fam Med 9: 738-742.

Steinbock RT 1976. Paleopathological Diagnosis and Interpretation, Thomas Publisher, Springfield, $423 \mathrm{pp}$. 
Tarragó M 1968. Secuencias culturales de la etapa Agroalfarera de San Pedro de Atacama, Chile. Actas y Memorias del XXXVII Congreso Internacional de Americanistas v.2, Buenos Aires, p. 119-145.

Topic JR, Topic TL 1997. La guerra Mochica. Rev Arqueol SIAN 4: 10-22.

Verano J 2000. Paleonthological analysis of sacrificial victims at the Pyramid of the Moon, Moche River Valley, Northern Peru. Chungará 32: 61-70.

Walker PL 1989. Cranial injuries as evidence of violence in pre- historic southern California. Am J Phys Anthropol 80: 313 323.

Walker PL 1997. Wife beating, boxing, and broken noses: skeletal evidence for the cultural patterning of violence. In DL Martin, DW Frayer (eds), Troubled Times: Violence and Warfare in the Past, Gordon and Breach Publishers, Amsterdam, p. 145-180.

Winter CT, Benavente MA, Massone CM 1985. Algunos efectos de Tiwanaku en la cultura de San Pedro de Atacama. Diálogo Andino 4: 259-275. 